\title{
PONDS SYRENIE STAWY IN SZCZECIN - CHANGES OF SELECTED WATER QUALITY CHEMICAL INDICES
}

\author{
SYRENIE STAWY W SZCZECINIE - ZMIANY WYBRANYCH \\ CHEMICZNYCH WSKAŹNIKÓW JAKOŚCI WODY
}

\begin{abstract}
The possibility of using - to a wider inference - water quality test results of stream Osowka flowing through ponds Syrenie Stawy in Szczecin (NW-Poland) - in particular the concentration of dissolved oxygen $(D O)$, electrical conductivity $(E C)$ and the total concentrations of nitrogen $(T N)$ and phosphorus $(T P)$ - conducted in the years 1994 to 2014 was analyzed. The examined indices were classified according to Official Standards currently in force in Poland. Changes of water quality as it flows through the ponds were identified. Multivariate linear regression equations were calculated, endearing statistically significant relationship between successive test indicators $\left(y_{i}\right)$ and other indices $\left(x_{i}\right)$ and deadlines for measurement periods $\left(T_{i}\right)$ has been made. This allowed in general to characterize water quality, determine the quality changes along the path of flow through ponds and discern what processes biohydrogeochemical within the ecosystem changes affected their quality.
\end{abstract}

Keywords: EU Water Framework Directive, artificial reservoirs, water quality, physical indices, chemical indices, ponds Syrenie Stawy, Szczecin

\section{Introduction}

Research on changes in water quality of streams flowing through lakes and ponds in urban areas, become in recent years - due to the environmental significance of these water bodies in cities- become a subject of many studies, which are presented in leading ecological journals [1-7].

In the current official regulations for testing the quality of surface waters in Poland [8] the surface water quality is determined on a scale from I to $\mathrm{V}$ class based on the inferior status: ecological and chemical. The ecological status is determined primarily on the basis of biocenoses in the audited water pond and its morphometric characteristics, and as auxiliary agents are taken into account a few selected physicochemical water quality indices whereas chemical status - based on the results of measurements of toxic substances in water specified in the above-mentioned legal act.

\footnotetext{
${ }^{1}$ Department of Chemistry and Natural Water Management, Szczecin University, ul. Z. Felczaka 3c, 71-412 Szczecin, Poland, phone +48 9144415 71, email: polesz@univ.szczecin.pl

*Corresponding author: polesz@univ.szczecin.pl
} 
As for physicochemical indices in the case of artificial water reservoirs in evaluating the ecological state need to be marked - mandatory - the following indices: water transparency, the concentration of dissolved oxygen $(D O)$, electrical conductivity of $20^{\circ} \mathrm{C}$ $(E C)$, the concentration of total nitrogen $(T N)$ and the total phosphorus concentration $(T P)$. Limit values - for evaluating the quality grade for each of the above indices are given in Annex 2 to the Regulation [8], while in the regulation are only the limits between I-II classes (in total) and III and the inferior water quality classes - even together.

The aim of this work was not to discern whether the results determinations such a small number of so-called supporting physicochemical indices (1 physical - transparency and 4 chemicals - DO, EC - as a measure of salinity and $T N, T P$ ) - can be the basis to the appropriate to apply for water quality artificial surface water reservoir. The aim of this study was to analyze whether the measurement results of these four water quality indices of stream Osowka flowing through ponds Syrenie Stawy in Szczecin during certain time periods (usually two-year) in long time period from 1994 to 2014, enable understanding of what changes the water quality occurred from 1994 to 2014, as well as what was the effectiveness of this ecosystem as a discharger and biological ponds and understanding the processes of bio-hydro-geo-chemical changes which affected the quality of water as it flows through ponds Syrenie Stawy.

\section{Ponds Syrenie Stawy characteristics}

Ponds Syrenie Stawy in Szczecin are located in areas "Team Parks Kasprowicz-Arkonski" - constituting a new form of nature conservation in Poland - in the NW part of the city of Szczecin $\left(53^{\circ} 27^{\prime} 26^{\prime \prime N}, 14^{\circ} 30^{\prime} 35^{\prime}\right.$ " E, elevation of the water surface $16.40 \mathrm{~m}$ a.s.1.) (Figs. 1 and 2). Ponds Syrenie Stawy were created after adjusting of the stream Osowka bed which was performed in the second half of the nineteenth century to retention of high water of precipitation water flowing down stream Osowka. In subsequent years, ponds Syrenie Stawy have also become reservoirs that collect rainwater from the streets of the city, and then to the Ponds wastewater from industrial plants were discharged, as well as periodically from slurry ponders. Input of pollutants has been reduced in the late 90s of the twentieth century. Mermaid ponds are reservoirs with a small area (pond No. 1 - approx. 0.15 ha, pond No. 2 - approx. 0.75 ha, pond No. 3 approx. 0.12 ha, pond No. 4 - about 0.10 ha - a total of approximately 1.15 ha) and a maximum depth of $2.0 \mathrm{~m}$. Water of stream Osowka flows sequentially through ponds No. 1, No. 2 and No. 3. Pond No. 4 is not a flow pond.

Ecosystem of ponds Syrenie Stawy was often tested. The results of hydro-chemical studies of ponds water, among others were presented for the example in works: Miller et al [9] and Poleszczuk et al [10], and the results of microbiological studies in works Deptula, Nahurska [11] and Sliwa-Dominiak and Deptula [12]. 


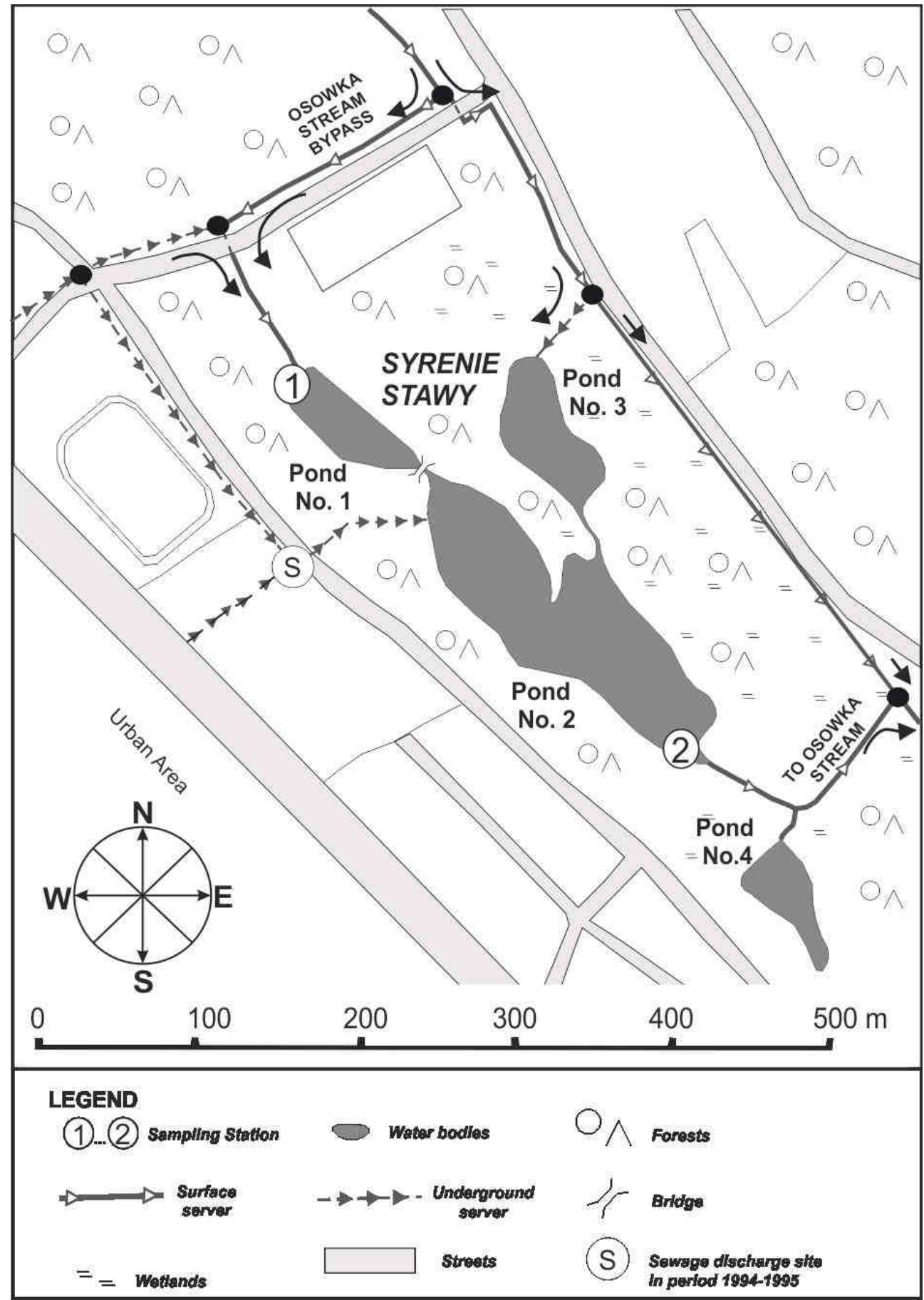

Fig. 1. Ponds Syrenie Stawy in Szczecin (NW-Poland) 


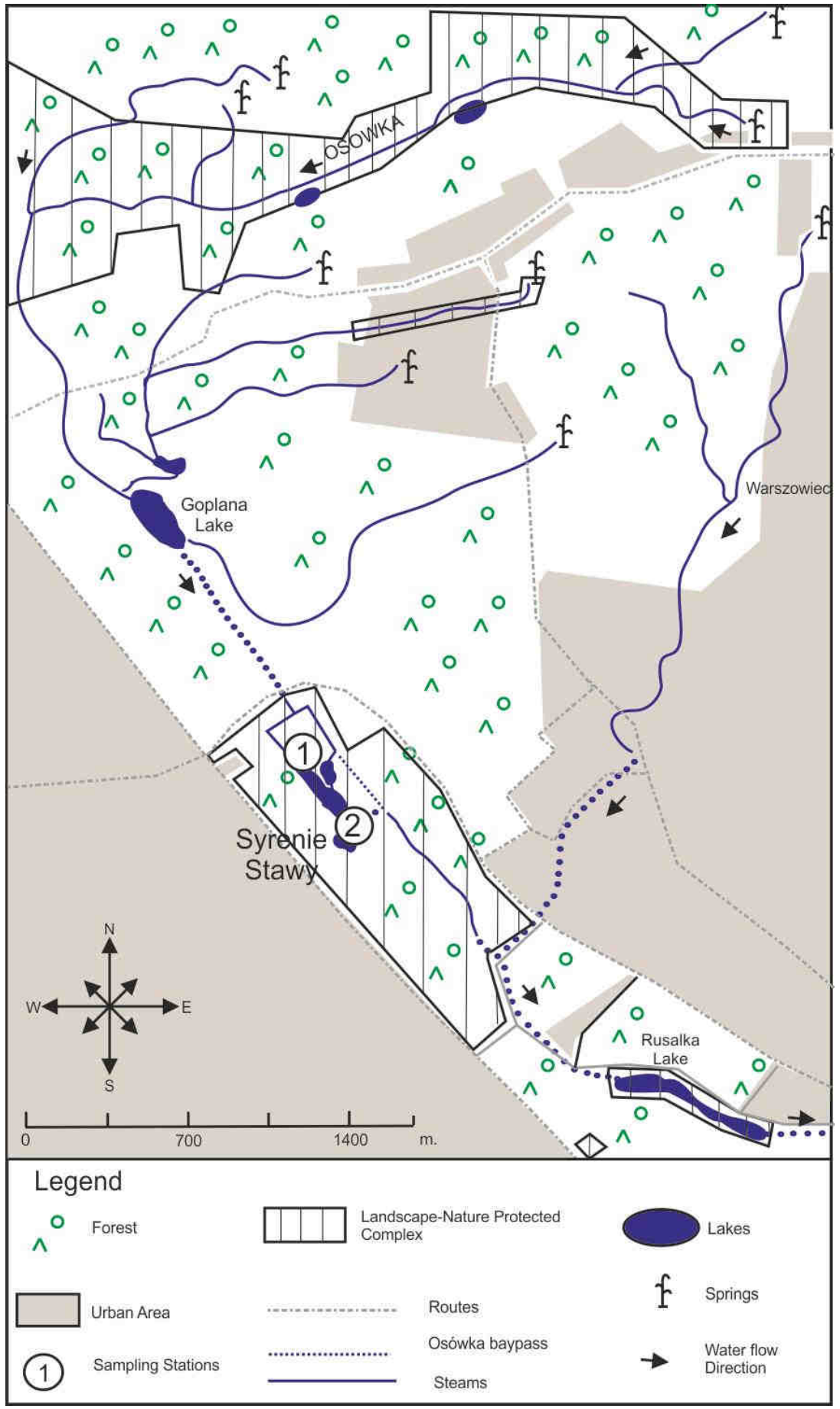

Fig. 2. Osowka Stream in Szczecin (NW-Polnad) 


\section{Material and methods}

Water samples from the ponds Syrenie Stawy was collected once a month in the years 1994-2014. Water was drawn from the surface layer (from a depth of 20-25 cm) at a distance of about $2.5 \mathrm{~m}$ from the shore in the area of stream Osowka water inflow to the pond No. 1 (Station No. 1) and in the water outflow area of from the pond No. 2 (Station No. 2). In collected water samples, usually, examinations of around 25 physicochemical water quality indices were performed. All assays were done according to procedures recommended by the APHA [13]. In this publication we used the results of $D O, E C, T N$ and $T P$ in accordance with Regulation [8]. Results of research realized in 1994 (April to December) and 1995 (January to December), and in the years 1999 and 2000 (January to December), as well as in the years 2006 and 2007 (from April to November) and 2014 year - from January to December - were used. The above time periods of sample collection were not chosen at random. In particular, in 1994-1995 ponds Syrenie Stawy were collecting container - albeit declining gradually - a significant amount of industrial wastewater and wastewater with slurry ponder and probably the so-called "wild" wastewater discharges, in 1999-2000 - after reducing the (at least formally) - discharge of different wastewaters into ponds Syrenie Stawy, while in 2006-2007 - after the regulation of sediments in 2003 and finally in 2014 - after more than two years (2010-2012) of hydrotechnical works, involving, inter alia, the removal of macrophytes, the dredging of reservoirs and strengthen fascine of shores.

In order to assess a statistically significant correlation between subsequent examined indices multivariate linear regression equation of sequentially engaging the relationship between $D O, E C, T N$ and $T P$ and so-called temporary factors $\left(T_{i}\right.$, where $\left.i=1 \ldots 4\right)$ assigned to each of specified time intervals also were calculated [14]:

$$
y_{i}=a_{0}+\sum_{i=1}^{n} a_{i} x_{i}+\sum_{i=1}^{n} b_{i} T_{i}+S E E
$$

where: $y_{i}$ - response function - in this case the following equations, in turn all examined water quality indices, ie $D O, E C, T N$ and $T P, x_{i}$ - further examined water quality indices after excluding one of the indicators as a function of response $y_{i}, S E E$ - standard error of estimation.

The equations were determined for numerical values of examined indices. $T_{i}$ parameter values recorded in the database as code (1.0). Multiple regression equations were calculated using the method and connecting stepper reject à priori (Forward) using the rejection criterion variable sequential test Fisher-Snedecor $F=4$ [15].

\section{Results}

The results are presented in the form of the statistical characteristics of the data sets for the years 1994-1995, 1999-2000 and 2006-2007 and 2014 are shown in Table 1, and all the measurement results are shown in Figures 3 and 4. In the diagrams in Figures 3 and 4 shows in the form of continuous lines parallel to the $x$-axis limits other parameters dividing the results into one, which had a magnitude considered I - II class and such - that had to be classified as III and inferior quality (according to Regulation [8] Annex No. 2 - for Schindler's coefficient of 3.50). 


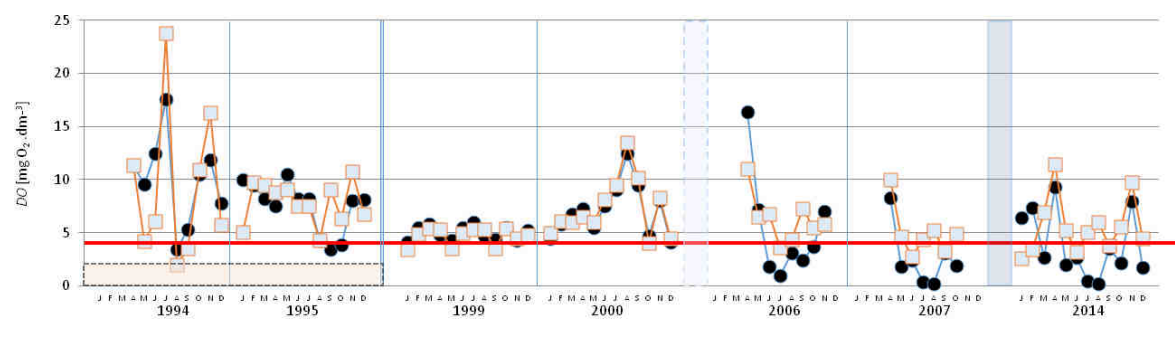

$\bar{\equiv} \frac{\frac{\mathscr{m}}{0}}{\stackrel{\frac{\pi}{5}}{\frac{0}{5}}}$
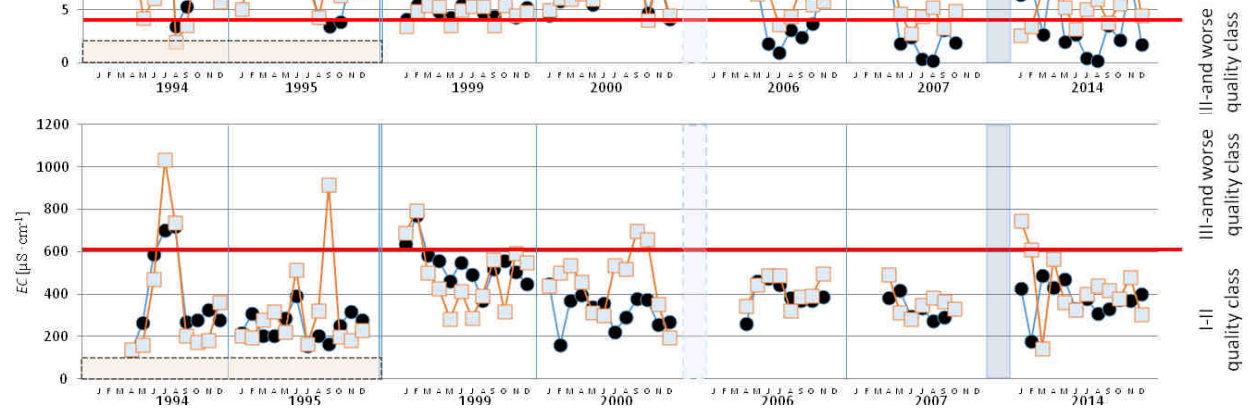

Fig. 3. Dissolved oxygen $(D O)$ concentrations and electrical conductivity $(E C)$ measuring results for ponds Syrenie Stawy in years 1994-2014 in inflow $(\bullet)$ and outflow (ם); Withdrawn gradually discharge of sewage from industrial plants and other sources; - Hydrotechnical regulations in year 2003; Hydrotechnical regulations in years 2010-2012; Line indicates the border value between first/second and third/lower water quality class
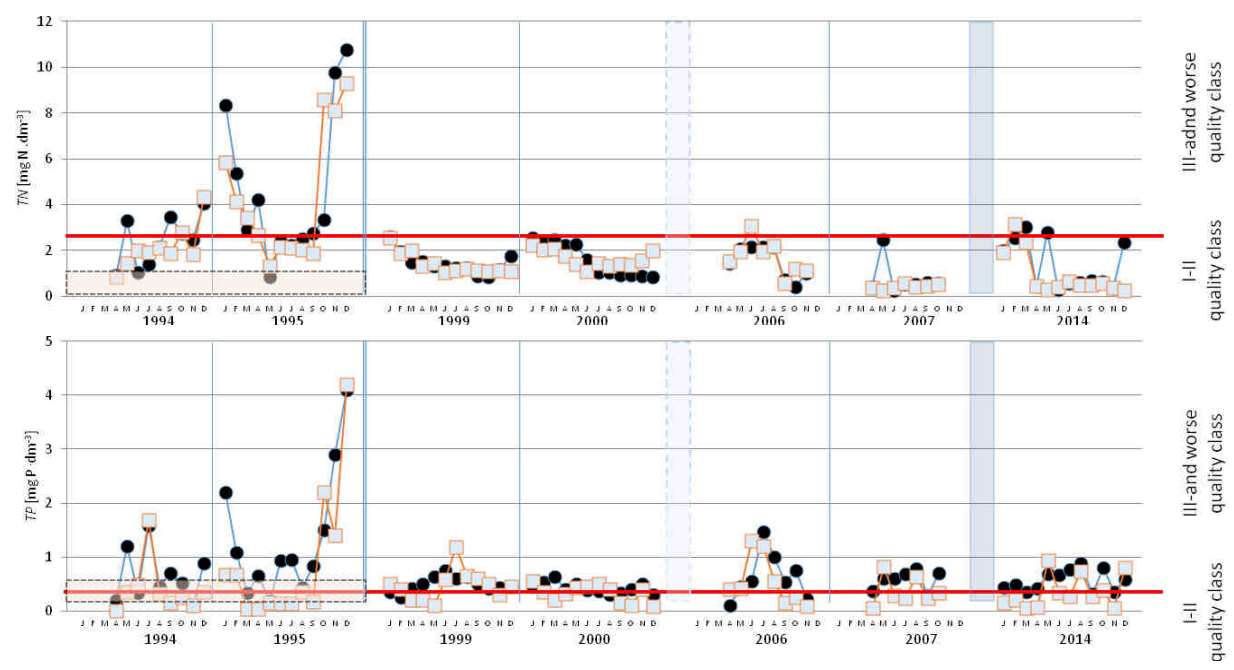

Fig. 4. Total nitrogen $(T N)$ concentrations and total phosphorus $(T P)$ concentrations measuring results for ponds Syrenie Stawy in years 1994-2014 in inflow (•) and outflow (ロ). Marks as in Figure 1

Figures 5 and 6 shows the differences $\Delta(D O), \Delta(E C), \Delta(T N)$ and $\Delta(T P)$ between the values of studied parameters at the outflow (Station No. 2) and inflow (Station No. 1) to/from ponds Syrenie Stawy. Calculated differences illustrate the changes 
in an approximate way - because we did not have discernment as to the retention time of water in the ponds.

Table 1

Statistical characteristics of data sets - inflow (Station No. 1) and outflow (Station No. 2) waters to/from ponds Syrenie Stawy

\begin{tabular}{|c|c|c|c|c|c|}
\hline \multicolumn{6}{|c|}{ Station No. 1} \\
\hline \multirow{2}{*}{$\begin{array}{c}\text { Water quality indices } \\
\text { [units] }\end{array}$} & \multirow{2}{*}{$\begin{array}{c}\text { Descriptive } \\
\text { statistics }\end{array}$} & \multicolumn{4}{|c|}{ Years } \\
\hline & & 1994-1995 & 1999-2000 & 2006-2007 & 2014 \\
\hline \multirow{3}{*}{$\begin{array}{c}D O \\
{\left[\mathrm{mg} \mathrm{O}_{2} \cdot \mathrm{dm}^{-3}\right]}\end{array}$} & Mean $\pm S D$ & $8.5 \pm 3.4$ & $6.0 \pm 2.1$ & $4.1 \pm 4.2$ & $3.9 \pm 3.1$ \\
\hline & Range & $3.4-17.6$ & $4.1-12.5$ & $0.2-16.4$ & $0.3-9.5$ \\
\hline & $C V$ & 0.40 & 0.34 & 1.05 & 0.80 \\
\hline \multirow{3}{*}{$\begin{array}{c}E C \\
{\left[\mu \mathrm{S} \cdot \mathrm{cm}^{-1}\right]}\end{array}$} & Mean $\pm S D$ & $312 \pm 160$ & $430 \pm 140$ & $366 \pm 68$ & $374 \pm 82$ \\
\hline & Range & $135-720$ & $160-770$ & $259-476$ & $179-489$ \\
\hline & $C V$ & 0.52 & 0.33 & 0.18 & 0.22 \\
\hline \multirow{3}{*}{$\begin{array}{c}T N \\
{\left[\mathrm{mg} \mathrm{N}^{-} \mathrm{dm}^{-3}\right]}\end{array}$} & Mean $\pm S D$ & $3.70 \pm 2.70$ & $1.52 \pm 0.61$ & $1.16 \pm 0.81$ & $1.40 \pm 1.10$ \\
\hline & Range & $0.80-10.80$ & $0.84-2.60$ & $0.25-2.46$ & $0.28-3.00$ \\
\hline & $C V$ & 0.74 & 0.40 & 0.70 & 0.79 \\
\hline \multirow{3}{*}{$\begin{array}{c}T P \\
{\left[\mathrm{mg} \mathrm{P}^{-} \mathrm{dm}^{-3}\right]}\end{array}$} & Mean $\pm S D$ & $1.05 \pm 0.98$ & $0.46 \pm 0.12$ & $0.61 \pm 0.33$ & $0.56 \pm 0.19$ \\
\hline & Range & $0.10-4.10$ & $0.26-0.75$ & $0.10-1.46$ & $0.33-0.88$ \\
\hline & $C V$ & 0.94 & 0.26 & 0.55 & 0.35 \\
\hline \multicolumn{6}{|c|}{ Station No. 2} \\
\hline \multirow{2}{*}{$\begin{array}{c}\text { Water quality indices } \\
\text { [units] }\end{array}$} & \multirow{2}{*}{$\begin{array}{c}\text { Descriptive } \\
\text { statistics }\end{array}$} & \multicolumn{4}{|c|}{ Year } \\
\hline & & 1994-1995 & 1999-2000 & 2006-2007 & 2014 \\
\hline \multirow{3}{*}{$\begin{array}{c}D O \\
{\left[\mathrm{mg} \mathrm{O}_{2} \cdot \mathrm{dm}^{-3}\right]}\end{array}$} & Mean $\pm S D$ & $8.3 \pm 4.7$ & $6.0 \pm 2.4$ & $5.7 \pm 2.3$ & $5.6 \pm 2.7$ \\
\hline & Range & $2.0-23.8$ & $3.4-13.5$ & $2.8-11.0$ & $2.6-11.5$ \\
\hline & $C V$ & 0.57 & 0.40 & 0.40 & 0.47 \\
\hline \multirow{3}{*}{$\begin{array}{c}E C \\
{\left[\mu \mathrm{S} \cdot \mathrm{cm}^{-1}\right]}\end{array}$} & Mean $\pm S D$ & $350 \pm 250$ & $472 \pm 150$ & $392 \pm 73$ & $431 \pm 160$ \\
\hline & Range & $160-1035$ & 194-795 & $283-496$ & $143-748$ \\
\hline & $C V$ & 0.72 & 0.32 & 0.18 & 0.36 \\
\hline \multirow{3}{*}{$\begin{array}{c}T N \\
{\left[\mathrm{mg} \mathrm{N}^{-} \mathrm{dm}^{-3}\right]}\end{array}$} & Mean $\pm S D$ & $3.80 \pm 2.90$ & $1.52 \pm 0.43$ & $1.10 \pm 0.86$ & $0.94 \pm 0.97$ \\
\hline & Range & $1.30-10.80$ & $1.04-2.54$ & $0.24-3.05$ & $0.23-3.16$ \\
\hline & $C V$ & 0.76 & 0.28 & 0.78 & 1.03 \\
\hline \multirow{3}{*}{$\begin{array}{c}T P \\
{\left[\mathrm{mg} \mathrm{P}^{\left.-\mathrm{dm}^{-3}\right]}\right.}\end{array}$} & Mean $\pm S D$ & $0.90 \pm 1.20$ & $0.40 \pm 0.24$ & $0.47 \pm 0.38$ & $0.35 \pm 0.30$ \\
\hline & Range & $0.03-4.20$ & $0.08-1.18$ & $0.06-1.30$ & 0.05-0.94 \\
\hline & $C V$ & 1.44 & 0.59 & 0.82 & 0.86 \\
\hline
\end{tabular}

$D O$ - dissolved oxygen, $E C$ - electrical conductivity, $T N$ - total nitrogen, $T P$ - total phosphorus

In turn, Table 2 shows the results of calculation of coefficients $a_{0}, a_{i}$ and $b_{i}$ in the equations of the linear multivariate regression enclosing the relationship between the values of the following water quality indices $\left(y_{i}\right)$, and the values of other measured indices $\left(x_{i}\right)$ and research terms $\left(T_{i}\right)$ for selected time intervals to the study. The comparison of data in Table 3 shows that the biohydrogeochemical processes taking place in the area of inflow and outflow of water of stream Osowka to / from ponds Syrenie Stawy were largely varied.

\section{Discussion}

Because the submitted data were selected so as to be able to analyze changes in water quality at different times in conditions of different anthropopressure, it was possible to attempt on their basis to discern, respectively - what was happening in the waters stream Osówka flowing through ponds Syrenie Stawy in 1994-1995, in the period of significant 
waste water pollution, then in 1999-2000 - after reducing the discharge of pollutants and later in 2006-2007 - after the refulation of sediments in 2003, and in 2014 - after an extensive hydrotechnical works in 2010-2012.

From the analysis of changes in water quality indices in subsequent intervals (Figs. 3 and 4), follows that the values of $D O, E C, T N$ and $T P$ in the tested waters for selected periods in the years 1994 to 2014 showed a specific variation, and - judging by criteria specified in the Regulation [8], which for obvious reasons in assessing the back - the concentration of $D O$ have a value corresponding to the I-II class water quality, with the exception of the results from 2006-2007 and 2014 - corresponding to the third and inferior class of quality, the EC - match almost always I-II class water quality, concentration $T N$ gradually decreased, keeping up - except for the years 1994-1995 - in I-II class of quality and the concentration of TP - were exceptions corresponding class III and inferior water quality, especially in the 1994-1995 and in 1999. These changes were synchronized with changes in the type and size of anthropopressure (changes of the pollutant inflow, hydrotechnical works) exerted on the ecosystem. Overall - the value of all four indicators analyzed in periods of research indicate that the tested waters were eutrophic [16].

Table 2

The values of coefficients $a_{0}, a_{i}$ and $b_{i}$ for a statistically significant equations $y_{i}=a_{0}+\sum_{i=1}^{n} a_{i} x_{i}+\sum_{i=1}^{n} b_{i} T_{i}+S E E$ showing dependence of the successive values of the response function for $D O, E C, T N$ and $T P$ from the remaining 3 out of 4 of water quality indices and terms $T_{i}$, ie selected periods of research in 1994-2014

\begin{tabular}{|c|c|c|c|c|c|c|c|c|c|c|c|}
\hline \multicolumn{12}{|c|}{ Station No. 1} \\
\hline \multirow[t]{2}{*}{$y_{i}$} & \multirow[t]{2}{*}{$a_{0}$} & \multicolumn{4}{|c|}{$a_{i}$ for $x_{i}$} & \multicolumn{4}{|c|}{$b_{i}$ for $T_{i}$} & \multicolumn{2}{|c|}{$\begin{array}{l}\text { Model fitting } \\
\text { coefficients }\end{array}$} \\
\hline & & $x_{1}$ & $x_{2}$ & $x_{3}$ & $x_{4}$ & $T_{1}$ & $T_{2}$ & $T_{3}$ & $T_{4}$ & $R^{2}$ & SEE \\
\hline$D O$ & $\begin{array}{c}0.81 \\
\pm 0.15\end{array}$ & & - * & $\begin{array}{l}-0.040 \\
\pm 0.110\end{array}$ & $\begin{array}{c}1.130 \\
\pm 0.100\end{array}$ & $-*$ & $\begin{array}{l}-1.06 \\
\pm 0.22\end{array}$ & - * & $-*$ & 0.81 & 0.86 \\
\hline$E C$ & $344 \pm 19$ & $-*$ & & $-*$ & $-*$ & $-*$ & $84 \pm 32$ & $-*$ & $-*$ & 0.27 & 13.06 \\
\hline$T N$ & $\begin{array}{l}-0.94 \\
\pm 0.38\end{array}$ & $-*$ & $\begin{array}{c}0.001 \\
\pm 0.001\end{array}$ & & $\begin{array}{c}0.843 \\
\pm 0.069\end{array}$ & $\begin{array}{c}0.62 \\
\pm 0.32\end{array}$ & $\begin{array}{c}1.18 \\
\pm 0.37\end{array}$ & - * & $-*$ & 0.77 & 0.93 \\
\hline$T P$ & $\begin{array}{c}1.34 \\
\pm 0.34 \\
\end{array}$ & $-*$ & $\begin{array}{l}-0.001 \\
\pm 0.001\end{array}$ & $\begin{array}{c}0.844 \\
\pm 0.056 \\
\end{array}$ & & - * & $\begin{array}{l}-0.97 \\
\pm 0.24\end{array}$ & - * & $-*$ & 0.77 & 0.91 \\
\hline \multicolumn{12}{|c|}{ Station No. 2} \\
\hline \multirow{2}{*}{$y_{i}$} & \multirow{2}{*}{$a_{0}$} & \multicolumn{4}{|c|}{$\mathbf{a}_{\mathrm{i}}$ for $x_{\mathrm{i}}$} & \multicolumn{4}{|c|}{$b_{i}$ for $T_{i}$} & \multicolumn{2}{|c|}{$\begin{array}{l}\text { Model fitting } \\
\text { coefficients }\end{array}$} \\
\hline & & $x_{1}$ & $x_{2}$ & $x_{3}$ & $x_{4}$ & $T_{1}$ & $T_{2}$ & $T_{3}$ & $T_{4}$ & $R^{2}$ & $S E E$ \\
\hline$D O$ & $4.1 \pm 1.0$ & & $\begin{array}{c}0.004 \\
\pm 0.002\end{array}$ & $-*$ & - * & $\begin{array}{c}3.03 \\
\pm 0.85\end{array}$ & - * & - * & $-*$ & 0.34 & 3.19 \\
\hline$E C$ & $389 \pm 48$ & $12 \pm 6$ & & $-*$ & $-*$ & $-146 \pm 51$ & $-*$ & $-64 \pm 54$ & $-*$ & \begin{tabular}{|l|}
0.28 \\
\end{tabular} & 17.55 \\
\hline$T N$ & $\begin{array}{l}-0.69 \\
\pm 0.36\end{array}$ & $\begin{array}{c}0.071 \\
\pm 0.044\end{array}$ & - * & & $\begin{array}{c}0.781 \\
\pm 0.098\end{array}$ & $\begin{array}{l}-0.53 \\
\pm 0.44\end{array}$ & $\begin{array}{c}0.59 \\
\pm 0.59\end{array}$ & - * & $-*$ & 0.53 & 1.18 \\
\hline$T P$ & $\begin{array}{c}1.06 \\
\pm 0.28 \\
\end{array}$ & $\begin{array}{l}-0.072 \\
\pm 0.039 \\
\end{array}$ & - * & $\begin{array}{c}0.620 \\
\pm 0.072 \\
\end{array}$ & & $\begin{array}{c}1.66 \\
\pm 0.30 \\
\end{array}$ & - * & - * & $-*$ & 0.63 & 1.05 \\
\hline
\end{tabular}

Values of $a_{0}, a_{i}$ and $b_{i}$ are statistically significant at the level $0.05>\alpha>0.10 ; x_{I}-D O$ $\left[\mathrm{mg} \mathrm{O}_{2} \cdot \mathrm{dm}^{-3}\right] ; x_{3}-T N\left[\mathrm{mg} \mathrm{N} \cdot \mathrm{dm}^{-3}\right] ; T_{1}, T_{2}, T_{3}, T_{4}$ - a measurement intervals - respectively: 1994-1995, 1999-2000, 2006-2007, 2014; $x_{2}-E C\left[\mu \mathrm{S} \cdot \mathrm{cm}^{-1}\right] ; x_{4}-T P\left[\mathrm{mg} \mathrm{P} \cdot \mathrm{dm}^{-3}\right]$; * lack of coefficients at the significance level $\alpha<0.05$ 


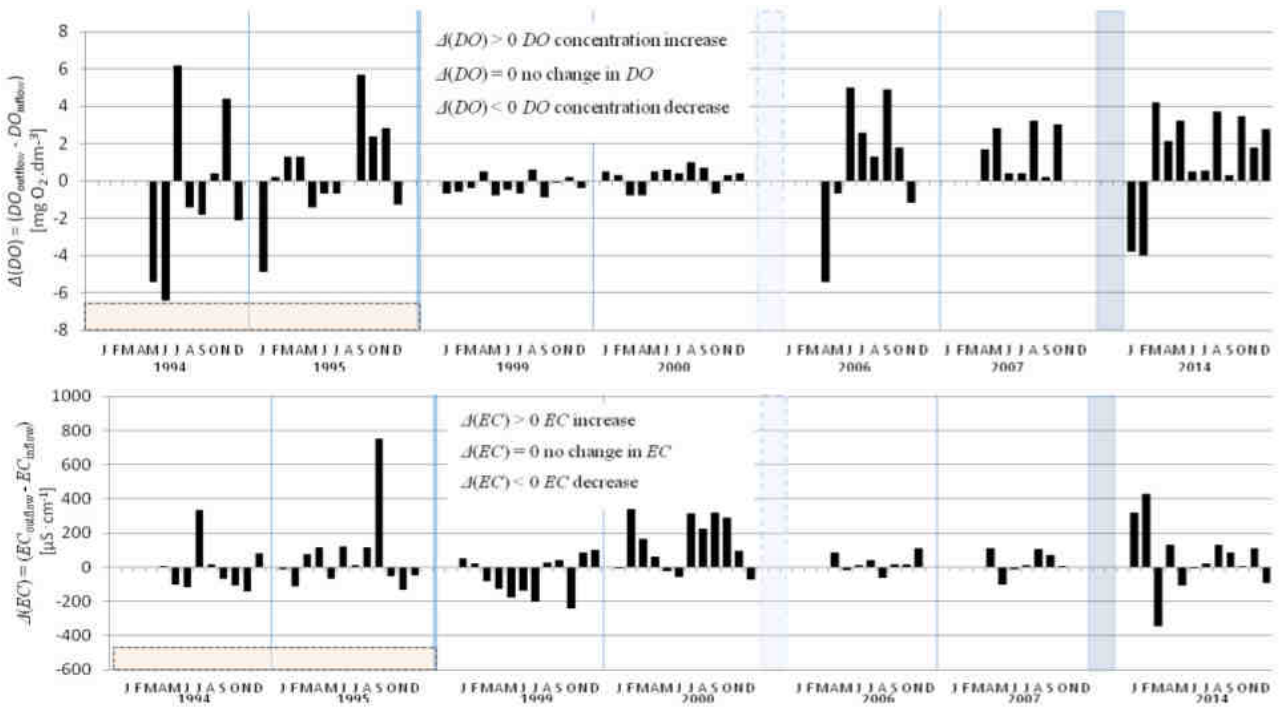

Fig. 5. Differences of dissolved oxygen concentrations between water outflow and inflow area $\Delta(D O)=\left(D O_{\text {outflow }}-D O_{\text {inflow }}\right)\left[\mathrm{mg} \mathrm{O}_{2} \cdot \mathrm{dm}^{-3}\right]$ in ponds Syrenie Stawy at day of sampling in years 1994-2014 and differences of electrical conductivity between water outflow and inflow area $\Delta(E C)=\left(E C_{\text {outflow }}-E C_{\text {inflow }}\right)\left[\mu \mathrm{S} \cdot \mathrm{cm}^{-1}\right]$ in ponds Syrenie Stawy at day of sampling in years 1994-2014. Marks as in Figure 1
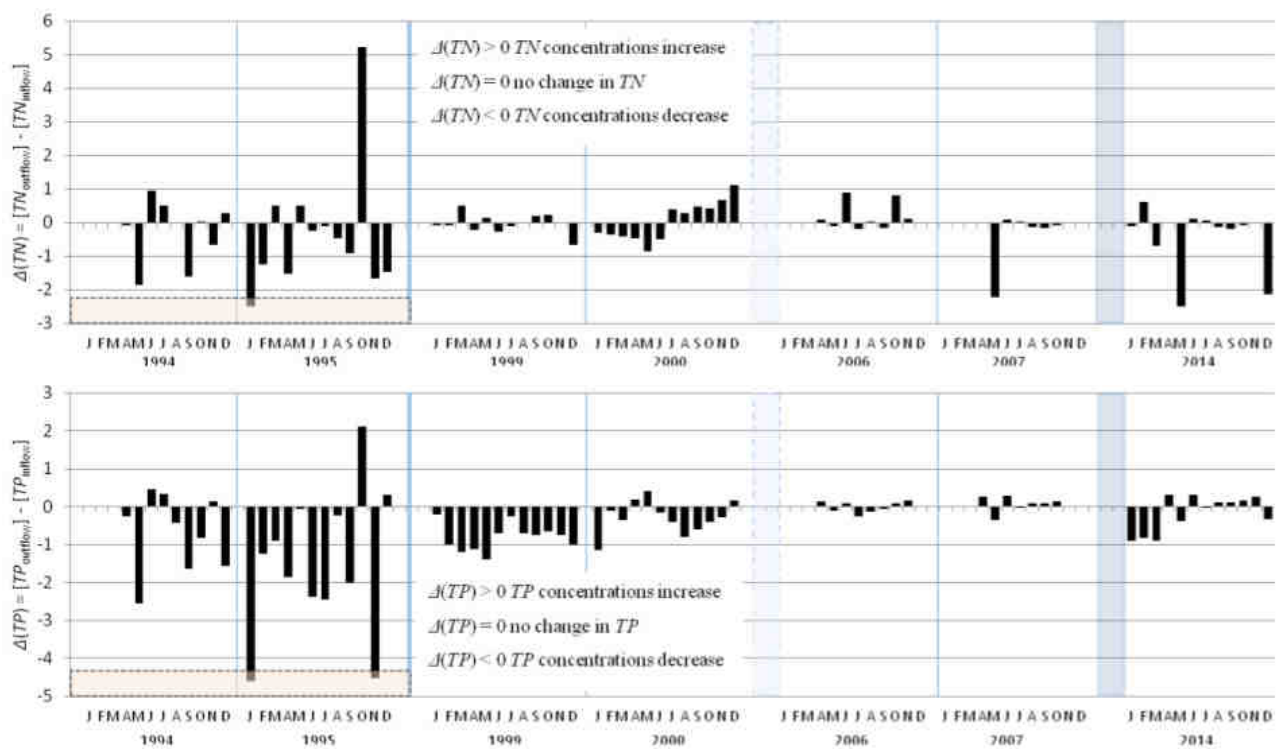

Fig. 6. Differences of total nitrogen concentrations between water outflow and inflow area $\Delta(T N)=\left(T N_{\text {outflow }}-T N_{\text {inflow }}\right)\left[\mathrm{mg} \mathrm{N} \cdot \mathrm{dm}^{-3}\right]$ in ponds Syrenie Stawy at day of sampling in years 1994-2014 and differences of total phosphorus concentrations between water outflow and inflow area $\Delta(T P)=\left(T P_{\text {outflow }}-T P_{\text {inflow }}\right)\left[\mathrm{mg} \mathrm{P} \cdot \mathrm{dm}^{-3}\right]$ in ponds Syrenie Stawy at day of sampling in years 1994-2014. Marks as in Figure 1 
In the years 1999-2000 specific changes in studied indices, and in fact no significant changes in all tested indices showed that the ponds Syrenie Stawy were at that time self-cleaning pond. A low values of $D O$ - water were significantly hypoxic - demonstrate that intensive oxidation of organic took place in the ecosystem, which was accompanied by the release to the water sufficiently high amounts of minerals ( $E C$ increase), as well as some amount of the phosphorus compounds ( $T P$ increase).

In the years 2006-2007 and 2014, after dredging the ponds Syrenie Stawy in 2003 and hydrotechnical works in 2010-2012, from the bottom sediments has been released significant amounts of various substances, which is evidenced by a specific variation of virtually all the tested quality indices.

On the basis of the differences between the various quality indices outflow and inflow from/to ponds Syrenie Stawy, ie $\Delta(D O), \Delta(E C), \Delta(T N)$ and $\Delta(T P)$ in subsequent dates of measurement - despite the fact that these differences were determined in an approximate way, due to the lack of knowledge of retention time of water in ponds Syrenie Stawy - it could be established that values of $\triangle(D O)$ 1994-1995 grew and fell irregularly, and since 2006 increased practically constantly. The values $\Delta(E C)$ and $\Delta(T N)$ after a period of significant volatility in 1994-1995 - stabilized, especially since 2006. On the other hand, values of $\Delta(T P)$ - usually decreasing in 1994-1995 and 1999, since 2000 were practically stable, which means that despite adverse changes in the studied parameters of water quality - by increasing the efficiency of processes of self-purification in the pond.

After determining the statistically significant coefficients in the equations of the linear regression multivariate (Table 2) could ascertain that a specific statistically significant correlations reasons to suggest that the increase oxygenation of water in the zone flow was associated with reproduction of phytoplankton biomass stimulated sufficiently with high abundance of water in the Pond no. 1 in a phosphorus compounds. Previously demonstrated [9], that water of stream Osowka above the ponds Syrenie Stawy contained very little phosphorus compounds (detected as $S R P$ and $T P$ ). It also showed a strong correlation of $T N$ and $T P$ in the ponds (inflow and outflow), which demonstrate the persistent of a significant amount of organic matter with a relatively stabilized molar ratios of $N: P$ in the water. The dependence of $E C$ and $D O$ in the area of the outflow waters shows that processes of organic matter mineralization in the ecosystem were respectively intensive.

\section{Conclusion}

On example of ponds Syrenie Stawy in Szczecin it has been shown that the conducted analysis of the functioning of ecosystems flow-ponds based on the results of multiannual examinations on the inflow and outflow of water to/from the pond water quality indices such as $D O, E C, T N$ and $T P$, studied as assist-indices in determining the ecological status of surface waters - it may be somewhat helpful to discern changes in the multiannual period and to identify the parts of the biohydrogeochemical processes involved in shaping water quality in selected ecosystem ponds.

\section{References}

[1] Wu Q, Xia X, Li X, Mou X. Impacts of meteorological variations on urban lake water quality: a sensitivity analysis for 12 urban lakes with different trophic states. Aquat Sci. 2014;76(3):339-351. DOI: 10.1007/s00027-014-0339-6. 
[2] Tu J. Spatial variations in the relationships between land use and water quality across an urbanization gradient in the watersheds of northern Georgia, USA. Environ Manage. 2013;51(1):1-17. DOI: 10.1007/s00267-011-9738-9.

[3] Singh SK, Singh P, Gautam SK. Appraisal of urban lake water quality through numerical index, multivariate statistics and earth observation data sets. Int $\mathrm{J}$ Environ Sci Tech. 2015;1-12. DOI: 10.1007/s13762-015-0850-x.

[4] Ismail NS, Dodd H, Sassoubre LM, Horne AJ, Boehm AB, Luthy RG. Improvement of urban lake water quality by removal of Escherichia coli through the action of the bivalve Anodonta californiensis. Environ Sci Tech. 2015;49(3):1664-1672. DOI: 10.1021/es5033212.

[5] Klimaszyk P, Rzymski P, Piotrowicz R, Joniak T. Contribution of surface runoff from forested areas to the chemistry of a through-flow lake. Environ Earth Sci. 2014;73(8):3963-3973. DOI: $10.1007 / \mathrm{s} 12665-014-3682-y$.

[6] Azizuddin AD, Ali NAM, Tay KS, Abas MRB, Simoneit BR. Characterization and sources of extractable organic matter from sediment cores of an urban lake (Tasik Perdana), Kuala Lumpur, Malaysia. Environ Earth Sci. 2014;71(10):4363-4377. DOI: 10.1007/s12665-013-2830-0.

[7] Rzymski P, Niedzielski P, Klimaszyk P., Poniedziałek B. Bioaccumulation of selected metals in bivalves (Unionidae) and Phragmites australis inhabiting a municipal water reservoir. Environ Monit Assess. 2014;186(5):3199-3212. DOI: 10.1007/s10661-013-3610-8.

[8] Journal of Laws of the Polish Republic. The Minister of Environment - 22 October 2014. On the classification of the status of surface waters and environmental quality standards for priority substances (DzU 2014, poz. 1482). http://isap.sejm.gov.pl/DetailsServlet?id=WDU20140001482.

[9] Miller T, Tokarz M, Poleszczuk G. Stream Osowka in Szczecin - chemometric analysis of water quality indices in winter season. Acta Biol. 2014;21:91-104. http://www.wb.usz.edu.pl/attachments/article/657/ 6-Miller.pdf .

[10] Poleszczuk G, Wawrzyniak W, Miller T, Tokarz M, Gasperowicz A, Adamczyk D. Syrenie Stawy in Szczecin - a comparison of the quality of waters in the winter and spring in 1994-1995, 1999-2000, 2006-2007 and 2014. In: Wawrzyniak W, Zaborowski T, editors. Ecology of Borderlands. Monography. Gorzow Wlkp.-Poznan: IBEN; 2014;122-137. DOI: 10.13140/2.1.2179.2006.

[11] Deptula W, Nahurska A. Sanitary studies on water of selected lakes in Szczecin. Polish J Environ Stud. 2004;13(6):693-702. http://www.pjoes.com/pdf/13.6/693-702.pdf.

[12] Sliwa-Dominiak J, Deptula W. Bacterial flora of water originating from Syrenie Stawy municipal lake in Szczecin. Polish J Environ Stud. 2009;18(3):455-466. http://www.pjoes.com/pdf/18.3/455-466.pdf.

[13] Standard methods for the examination of water and wastewater: American Public Health Association. Washington: APHA; 1992.

[14] Halstead JA, Kliman S, Berheide CW, Chaucer A, Cock-Esteb A. Urban stream syndrome in a small, lightly developed watershed: a statistical analysis of water chemistry parameters, land use patterns, and natural sources. Environ Monit Assess. 2014;186(6):3391-3414. DOI: 10.1007/s10661-014-3625-9.

[15] Statistica for Windows. General Conventions and Statistics. Tulsa: StatSoft; 1994. http://www.statsoft.pl/textbook/stathome.html.

[16] Dojlido JR, Best GA. Chemistry of Water and Water Pollution. New York: Ellis Horwood; 1993. 


\title{
SYRENIE STAWY W SZCZECINIE - ZMIANY WYBRANYCH CHEMICZNYCH WSKAŹNIKÓW JAKOŚCI WODY
}

\author{
Wydział Biologii, Uniwersytet Szczeciński
}

\begin{abstract}
Abstrakt: Analizowano możliwość wykorzystania - do poszerzonego wnioskowania - wyników oznaczeń fizyczno-chemicznych wskaźników jakości wód oznaczanych przy określaniu stanu ekologicznego wód powierzchniowych strumienia Osówka przepływających przez Syrenie Stawy w Szczecinie (NW-Polska), tj. stężenie rozpuszczonego tlenu $(D O)$, przewodnictwo elektrycznego $(E C)$ oraz ogólne stężenia azotu $(T N)$ i fosforu (TP) przeprowadzone w latach 1994-2014. Badane wskaźniki klasyfikowano według standardów aktualnie obowiązujących w Polsce w przepisach urzędowych. Oszacowano także zmiany jakości wód podczas przepływu przez stawy oraz obliczono równania regresji liniowej wieloczynnikowej, ujmujące statystycznie istotne zależności pomiędzy kolejnymi badanymi wskaźnikami $\left(y_{i}\right)$ i pozostałymi wskaźnikami $\left(x_{i}\right)$ oraz terminami okresów pomiarowych $\left(T_{i}\right)$. Pozwoliło to ogólnie scharakteryzować jakość wód, określić zmiany jakości wzdłuż drogi ich spływu przez stawy oraz poznać, jakie procesy biohydrogeochemiczne zachodzące w ekosystemie wpływały na zmiany ich jakości.
\end{abstract}

Słowa kluczowe: Ramowa Dyrektywa Wodna, sztuczny zbiornik wodny, jakość wody, wskaźniki fizyczne, wskaźniki chemiczne, Syrenie Stawy, Szczecin 